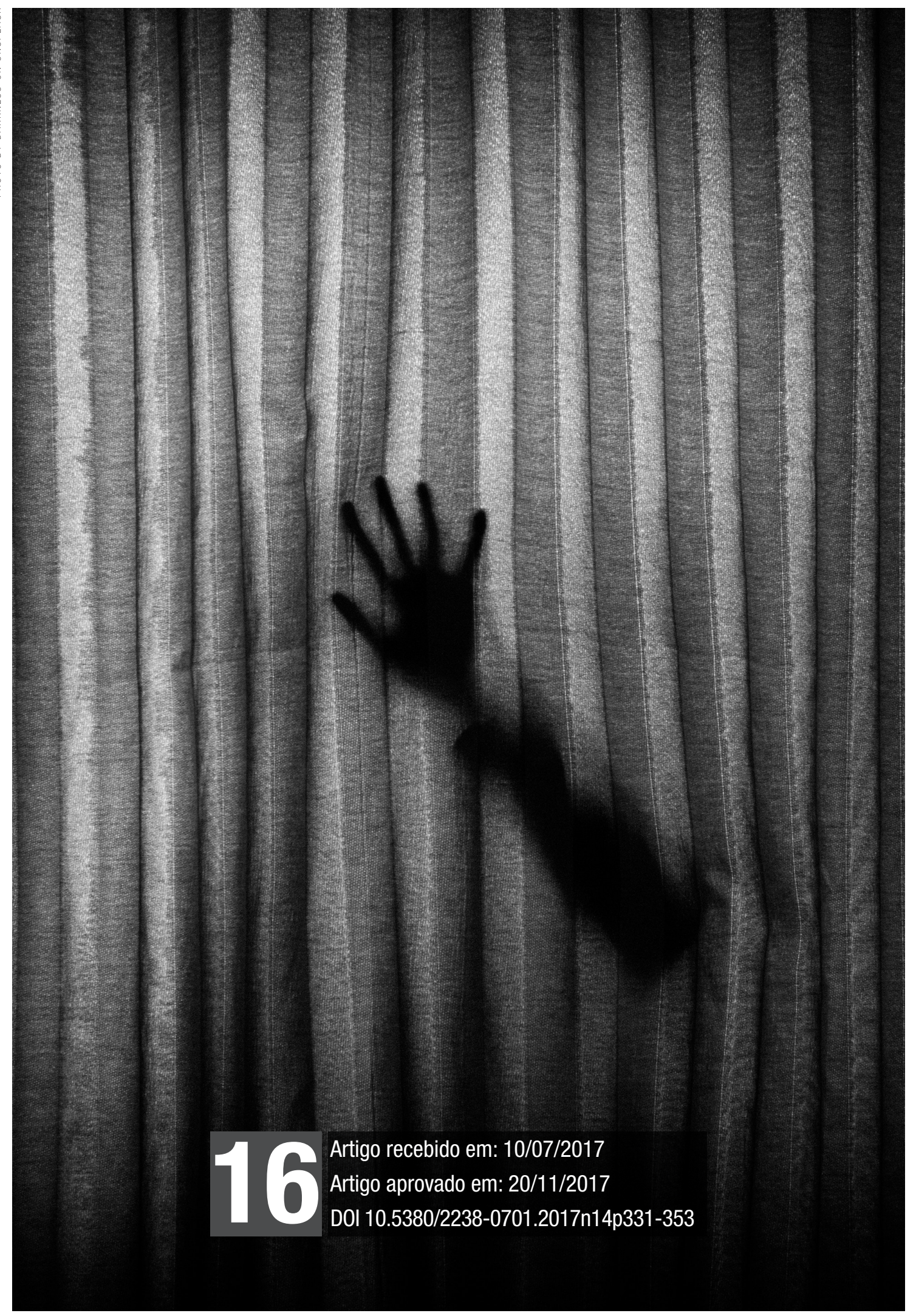


Ecossistemas comunicacionais. Cibercultura. Estéticas da violência. 


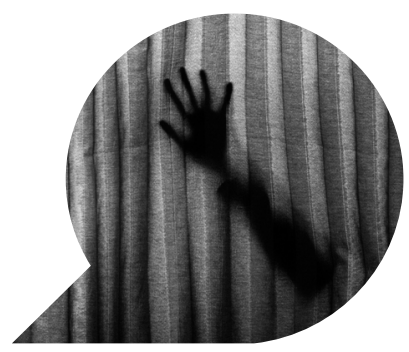

\title{
A rebelião no Compaj e a estética da violência no contexto cibercultural e ecossistêmico
}

\author{
Riot in Compaj and the aesthetic of violence in the context \\ cybercultural and ecosystem
}

El motim en el Compaj y la estética de la violencia en el
contexto cibercultural y ecosistémico

\begin{tabular}{c}
\hline GILSON VIEIRA MONTEIRO $^{*}$ \\
\hline ADRIANO SILVA RODRIGUES $^{\star *}$ \\
\hline RAFAEL DE FIGUEIREDO LOPES $^{\star * *}$
\end{tabular}

Resumo: Neste artigo propõe-se uma reflexão sobre a estetização da violência no contexto cibercultural e ecossistêmico. Parte-se de apontamentos sobre a rebelião no Compaj (Complexo Penitenciário Anísio Jobim), ocorrida em Manaus (em 2017), considerada

\footnotetext{
* Doutor em Ciências da Comunicação (USP), mestre em Administração (USP) e bacharel em Comunicação Social (UFAM). Docente dos Programas de Pós-Graduação em Ciências da Comunicação e em Sociedade e Cultura na Amazonia da UFAM. É coordenador do Programa de Mídias Digitais da UFAM (ECOEM/UFAM), líder do MIMO (Grupo de Pesquisa Mídia, Moda e Linguagens - UFAM/CNPq). Bolsista do CNPq em Desenvolvimento Tecnológico e Extensão Inovadora. E-mail: gilsonmonteiro@ufam.edu.br. ** Mestre em Ciências da Comunicação (UFAM), bacharel em Comunicação Social (UNAMA). Integrante do MIMO (Grupo de Pesquisa Mídia, Moda e Linguagens - UFAM/CNPq). Bolsista da Fapeam. E-mail: adrianorodriguespa@gmail.com.

*** Doutorando em Sociedade e Cultura na Amazônia (UFAM), mestre em Ciências da Comunicação (UFAM), bacharel em Comunicação Social (UFRR). Integrante do MIMO (Grupo de Pesquisa Mídia, Moda e Linguagens - UFAM/CNPq). Bolsista da Capes. E-mail: rafaflopes@bol.com.br.
} 
uma das maiores chacinas penitenciárias do Brasil. A estratégia teórico-metodológica segue o viés dos Ecossistemas Comunicacionais, buscando compreender o fenômeno por meio de inter -relações e interdependências. Assim, percebe-se que na contemporaneidade, imagens, emoções, sensações, pensamentos e ações corporificam-se no espaço hipermidiático, potencializando a banalização imagético-sensorial da violência no adormecimento de seus sentidos mais complexos.

Palavras-chave: Comunicação; Ecossistemas Comunicacionais; Cibercultura; Estéticas da Violência; Compaj.

Abstract: In this paper we propose to reflect on the aestheticization of violence in the cybercultural and ecosystem context. There are notes on the riot in Compaj (Complexo Penitenciário Anísio Jobim), in Manaus (in 2017), one of the biggest prison riots in Brazil. The theoretical and methodological strategy is interdisciplinary, based on the perspective of the Communication Ecosystems. We conclude that images, emotions, sensations, thoughts and actions are embodied in the hypermiditic space. In this way, the violence is trivialized minimizing its complex senses.

Keywords: Communication; Communication Ecosystems; Cyberculture; Aesthetics of Violence; Compaj.

Resumen: En este artículo se propone una reflexión sobre la estetización de la violencia en el contexto cibercultural y ecosistémico. Se parte de apuntes sobre la rebelión en el Compaj (Complejo Penitenciario Anísio Jobim), en Manaus (en 2017), uno de los mayores disturbios penitenciarios de Brasil. La estrategia teórico y metodológica es interdisciplinaria, basada en la perspectiva de los Ecosistemas Comunicacionales. Así, se percibe que en la contemporaneidad, imágenes, emociones, sensaciones, pensamientos y acciones se corporalizan en el espacio hipermidiático, potenciando la banalización estética de la violencia y amortizando sus sentidos más complejos.

Palabras clave: Comunicación; Ecossistemas Comunicacionales; Cibercultura; Estéticas de la Violencia; Compaj. 


\section{Introdução}

O ano de 2017 começou marcado por uma série de rebeliões em presídios brasileiros, causadas por disputas de poder entre facções do crime organizado. Só nas duas primeiras semanas de janeiro foram registradas chacinas em três estados, Amazonas, Roraima e Rio Grande do Norte, além de rebeliões em outras regiões, resultando em 134 mortes oficiais nesse curto período. Em comparação ao ano anterior o número equivale a $37 \%$ dos assassinatos em penitenciárias no Brasil, pois em 2016 foram 372 mortes (CARTA CAPITAL, 2017; ÉPOCA, 2017; MÍDIA NINJA, 2017; UOL, 2017).

Salienta-se que além das rebeliões citadas outros conflitos, fugas e mortes foram registrados em diversas unidades prisionais brasileiras nas primeiras semanas do ano e outras se sucederam. O caso do Amazonas, entretanto, chama a atenção porque envolve uma sequência de motins em unidades prisionais de Manaus. O maior ocorreu em $1^{\circ}$ de janeiro de 2017, no Complexo Prisional Anísio Jobim (Compaj) ${ }^{1}$, localizado na zona rural, quando 56 presos foram assassinados e 184 fugiram (UOL, 2017). No dia seguinte, na Unidade Prisional do Puraquequara, na zona oeste da cidade, foram quatro vítimas. Em 08 de janeiro, na Cadeia Pública Raimundo Vidal Pessoa, no centro da capital amazonense, mais quatro pessoas morreram assassinadas. Já em Roraima o massacre ocorreu em 06 de janeiro, na Penitenciária Agrícola de Monte Cristo, na zona rural da capital Boa Vista, resultando em 33 vítimas. No Rio Grande do Norte, no dia 14 de janeiro, 26 pessoas foram mortas na Penitenciária de Alcaçuz, na região metropolitana de Natal (CARTA CAPITAL, 2017; ÉPOCA, 2017; FOLHA DE S.PAULO, 2017; JORNAL NACIONAL, 2017).

Além da violência engendrada nos motins também chama a atenção a maneira extremamente estetizada como os internos articularam a produção de imagens e a divulgação dos acontecimentos pelas redes sociais da internet, de dentro das próprias unidades prisionais ou durante as fugas. Diante destes fatos, propomos uma reflexão sobre a estetização da violência no contexto cibercultural, priorizando apontamentos ecossistêmicos sobre a rebelião no Compaj, considerada uma das maiores chacinas penitenciárias da história no Brasil.

${ }^{1}$ O Compaj está localizado a cerca de 30 quilômetros do centro de Manaus e tem acesso pela BR 174 que liga a capital amazonense ao estado de Roraima e à Venezuela. No dia da rebelião a unidade que tem capacidade para 454 presos abrigava 1224 detentos. 
A abordagem segue o viés dos Ecossistemas Comunicacionais ${ }^{2}$, uma perspectiva emergente no campo da Comunicação, com desdobramentos investigativos e lastro institucional na Universidade Federal do Amazonas, inclusive, como área de concentração do Programa de Pós-Graduação em Ciências da Comunicação. Iniciado em 2008, foi o primeiro Programa de Pós-Graduação em Comunicação do Norte do Brasil a ser aprovado pela Coordenação de Aperfeiçoamento de Pessoal de Nível Superior (Capes). Suas investigações são guiadas por duas linhas de pesquisa: Redes e processos comunicacionais, e Linguagens, representações e estéticas comunicacionais (MONTEIRO; ABBUD; PEREIRA, 2012).

Trata-se de uma proposta inter e transdisciplinar, que investiga os fenômenos comunicacionais pelas interações entre o ser humano, o ambiente, a cultura e a tecnologia, procurando evidenciar suas inter-relações e interdependências. Ao pensar de forma ecossistêmica o pesquisador não aparta as subjetividades, incertezas e os afetos da investigação científica. Portanto, contrasta com o funcionalismo de algumas teorias clássicas da comunicação, focadas em causas e efeitos, seguindo um esquema emissor, mensagem e receptor (MONTEIRO, 2017).

A concepção de Ecossistemas Comunicacionais, no entanto, não tem intenção de tornar-se uma nova Teoria da Comunicação. Mas, se estrutura na medida em que reestrutura seus objetos, em mutáveis relações sistêmicas e complexas. Desse modo, surge como uma possibilidade de estudo inter e transdisciplinar para compreender aspectos dos fluxos comunicacionais, sem com isso ter a pretensão de oferecer uma visão totalizante sobre os fenômenos (COLFERAI, 2014). É uma perspectiva que emerge da Amazônia, como uma alternativa aos estudos no campo da Comunicação, sobretudo, a partir de proposições com diferentes interfaces suscitadas por pesquisadores como Gilson Monteiro (mídias digitais), Mirna Pereira (semiótica) e Sandro Colferai (sociedade e cultura).

Assim sendo, o desenvolvimento da perspectiva ecossistêmica proposta pelos pesquisadores da UFAM, compreende estudos sobre os processos de organização, transformação, produção, circulação e consumo em ambientes comunicacionais conformados pelas interações entre sistemas sociais, culturais e tecnológicos, considerando a complexidade

\footnotetext{
${ }^{2}$ Pelo fato de ser uma abordagem ainda em emergência no campo da Comunicação, optamos por enfatizar alguns dos seus preceitos conceituais reforçando que esta perspectiva permeia toda a discussão proposta neste artigo.
} 
sistêmica e informacional dos fenômenos comunicativos (MONTEIRO; ABBUD, PEREIRA, 2012). Neste sentido, os processos comunicacionais são percebidos e investigados não a partir do isolamento de suas partes, mas da diversidade de redes de fenômenos interconectados e interdependentes manifestos nas diferentes instâncias da cultura em pesquisas interdisciplinares (COLFERAI, 2014).

Portanto, neste artigo, sugerimos uma trama panorâmica entre diferentes autores e campos do conhecimento para estabelecermos múltiplas conexões sobre as rebeliões em Manaus e suas representações estéticas, sinalizando inúmeras possibilidades e arranjos que podem ser articulados numa interpretação compreensiva, na aproximação entre comunicação, cultura, aparatos tecnológicos e a sociedade cibercultural.

Além do embasamento bibliográfico, sugerimos como estratégia de investigação uma espécie de cartografia do acaso, considerando a intersubjetividade permitida pela perspectiva ecossistêmica. A ideia foi proposta em reunião do Grupo de Pesquisa Mídia Moda e Linguagens (UFAM/CNPq), do qual fazemos parte, durante o desenrolar das rebeliões, portanto, sem o afastamento estratégico do ponto de vista de uma análise mais fria sobre os fatos, pois eles estavam acontecendo muito próximos de nós. Optamos por acompanhar como as rebeliões eram noticiadas por reportagens publicadas em alguns sites de repercussão nacional ${ }^{3}$ e mantivemos a atenção sobre o material que também circulava pelas redes sociais da internet, a partir do que era produzido pelos amotinados de dentro das unidades prisionais e também postados no YouTube, durante três semanas a partir do início da sequência de motins. Esta articulação metodológica nos proporcionou reflexões relacionais entre o que era produzido pelos detentos, o noticiário institucionalizado e o contexto sociocultural e histórico.

Cabe salientar, entretanto, que esta opção pelo foco no ambiente online tem inspiração na netnografia (AMARAL; NATAL; VIANA, 2008), aporte metodológico de pesquisa em comunicação no meio digital, que

\footnotetext{
3 Tomou-se como base dez publicações online (BBC BRASIL, 2017; CARTA CAPITAL, 2017; ÉPOCA, 2017; FOLHA DE S.PAULO, 2017; JORNAL NACIONAL, 2017; MÍDIA NINJA, 2017; O GLOBO, 2017; PASTORAL CARCERÁRIA, 2017; UOL, 2017; VEJA, 2017), escolhidas de forma aleatória pelo que estamos chamando de "cartografia do acaso", ou seja, guiada por critérios intersubjetivos inerentes aos pesquisadores. Percebe-se que a maioria das reportagens se utilizam de dados divulgados pelo Ministério da Justiça e situações confirmadas por órgãos de Segurança Pública, sem dar tanto espaço às "vozes dissonantes" do sistema de poder instituído pelo Estado. Essa questão da marginalização de determinados discursos e da afirmação das divulgações oficiais é apenas um apontamento contextual, já que para embasarmos e aprofundarmos tal discussão precisaríamos adentrar por outras trilhas (como o pensamento pós-colonial, a sociologia das emergências entre outras epistemologias alternativas das ciências sociais) e que neste momento preferimos não percorrer.
} 
analisa o comportamento e as dinâmicas de sujeitos e grupos sociais na internet. É embasada na etnografia, método antropológico de pesquisa de campo para coleta, análise e interpretação de dados, configurado pelo caráter intersubjetivo entre pesquisador e objeto. Embora a netnografia, como transposição virtual da pesquisa participante, apresente vantagens de ordem prática, perde as minúcias do comportamento natural dos sujeitos, do contato direto e suas interlocuções (AMARAL; NATAL; VIANA, 2008).

Nesse sentido, o que propomos é uma possibilidade de leitura para esta conjunção de fatores, apresentando uma maneira ecossistêmica de compreender representações estéticas em atos violentos de rebeliões em Manaus, procurando relações universais com a estetização e espetacularização do grotesco. Ou seja, configurando um ecossistema comunicacional nos dinâmicos fluxos da sociedade cibercultural. Desse modo, esperamos exercitar reflexões, levando em consideração as interdependências e inter-relações entre fatores sociais e políticos que ocasionam problemas no sistema penitenciário brasileiro, as condições ambientais (espaço) que interferem na vida dos sujeitos, que por sua vez se apropriam das possibilidades tecnológicas e das suas dinâmicas possibilidades comunicacionais.

\section{Contexto: a crise-crônica no sistema penitenciário brasileiro}

Embora nosso foco seja a estetização da violência, tomando como base o material produzido durante o motim do Compaj, é necessário configurar um cenário relacional, no sentido de contextualizar brevemente alguns aspectos políticos e sociais sobre a crise-crônica do sistema penitenciário brasileiro. Esse panorama é o que permite pinçarmos fios compreensivos e estabelecermos alguns nexos sobre as rebeliões ocorridas no início de 2017 e atentarmos com mais ênfase para o caso de Manaus.

Sendo assim, começamos enfatizando que o Estado só divulgou um plano de ação (diante da sequência de motins em unidades prisionais brasileiras) quase três semanas após o início dos motins. No dia 17 de janeiro de 2017, foram veiculadas reportagens informando que o Governo Federal autorizou a atuação das Forças Armadas nos presídios por 12 meses (até o início de 2018), mediante solicitação dos governos estaduais, em ações integradas com as polícias, a fim de encontrar armas, drogas e celulares (FOLHA DE S.PAULO, 2017; JORNAL NACIONAL, 2017). 
Esse posicionamento do Governo expõe algumas das medidas do Plano Nacional de Segurança, que também prevê a transferência de líderes de facções para presídios federais, a instalação imediata de núcleos de inteligência policial em todos os estados, a atuação integrada para abrir novas vagas em presídios com alas e prédios modulares, a compra de bloqueadores de celular, scanners e tornozeleiras, além de propor uma mudança na Constituição para criar uma nova fonte de financiamento para a segurança pública, com repasse obrigatório, como há para a saúde e a educação (JORNAL NACIONAL, 2017).

O motim do Compaj, em Manaus, é considerado o maior massacre registrado no sistema penitenciário do país desde a chacina do Carandiru ${ }^{4}$. Conforme autoridades de Segurança Pública do Amazonas e do Ministério da Justiça, a rebelião que durou cerca de 17 horas foi causada pela disputa de poder entre integrantes de quadrilhas ligadas ao tráfico de drogas, o Primeiro Comando da Capital (PCC), Considerada a maior organização criminosa brasileira, dominando os presídios paulistas (AMORIM, 2003) e a Família do Norte (FDN), que é uma facção regional aliada ao Comando Vermelho (CV), facção criminosa com origem no Rio de Janeiro e que possui laços com as FARC da Colômbia (AMORIM, 2003).

Algumas das reportagens que foram tomadas como base para este estudo informam que desde setembro de 2016 a cúpula do PCC havia declarado guerra ao $\mathrm{CV}$, com ordem de matança aos integrantes da facção rival, devido ao rompimento de um acordo que até então ambas mantinham para a compra de drogas e armas em regiões de fronteira do Brasil com o Paraguai, Bolívia, Peru e Colômbia (CARTA CAPITAL, 2017; BBC BRASIL, 2017; ÉPOCA, 2017; MÍDIA NINJA, 2017; O GLOBO, 2017). Segundo os sites, essa ordem teria se espalhado via WhatsApp entre presídios que não conseguem barrar a circulação de informações por meio de celulares. Como resposta, os integrantes da FDN, no Compaj, teriam se organizado para neutralizar a ação do PCC, matando os integrantes da facção que estavam presos na unidade. As reportagens afirmam que, conforme as investigações dos órgãos de segurança, as mortes em Manaus teriam desencadeado a rebelião de Boa Vista. Na ocasião, membros do PCC, em ato de vingança, assassinaram filiados à FDN. Depois, no Rio Grande do Norte, integrantes do PPC mataram detentos ligados ao $\mathrm{CV}$, enfatizam as reportagens.

\footnotetext{
${ }^{4}$ A rebelião na Casa de Detenção de São Paulo (Carandiru) ocorrida em 1992 é considerado o maior massacre penitenciário no Brasil, resultando na morte de 111 detentos (PIETÁ; PEREIRA, 1993).
} 
Assim, ao observarmos essa configuração por uma ótica ecossistêmica, num exercício reflexivo, podemos sugerir que as rebeliões provocaram uma rede de violência que se espalhou por outras unidades prisionais, evidenciando um problema crônico da realidade social brasileira que é a crise do sistema penitenciário. A rede de interconexões e interdependências, em se tratando do sistema penitenciário, é de grande complexidade. Podemos pensar desde os inúmeros fatores que podem levar uma pessoa para a criminalidade (como a miséria, conflitos psicológicos, a falta de oportunidades, a opressão, etc.), também temos que considerar o sistema jurídico com suas leis, as diferentes formas de cumprimento de penas, a situação das unidades de detenção, bem como as relações que acabam se estabelecendo nesses processos e em suas implicações, quase sempre corruptíveis em quaisquer instâncias. É um tecido que perpassa por questões do ser humano, do Estado, da sociedade, de ideologias, de poder econômico e de manipulação midiática.

Algumas das reportagens analisadas apontam que entidades de direitos humanos reforçam a ineficiência das políticas voltadas à gestão da segurança pública, bem como a superlotação e as condições de precariedade (de infraestrutura física e humana) dos presídios criam um ambiente propício para a proliferação de ações criminosas, sobretudo, voltadas ao narcotráfico (PASTORAL CARCERÁRIA, 2017; MÍDIA NINJA, 2017). As facções possuem estatutos próprios, com preceitos de hierarquia, disciplina e códigos de honra, moral e ética, cada qual configurando sua estrutura de poder social, econômico e governamental (paralelamente à estrutura estatal), gerando uma instabilidade constante e fazendo das unidades prisionais territórios de conflito e brutalidade, reforçando que o sistema vigente não tem resultado em melhorias para a recuperação humanizada e a reintegração social dos detentos (PASTORAL CARCERÁRIA, 2017).

Para a Pastoral Carcerária da Igreja Católica (PASTORAL CARCERÁRIA, 2017), a espetacularização midiática em torno da pauta "guerra entre facções" apenas desvia o foco do problema do encarceramento no Brasil, que desde a década de 1990 aumentou em sete vezes, chegando atualmente a cerca de 1 milhão de pessoas sob a tutela penal, conforme dados do Conselho Nacional de Justiça. Na visão da organização religiosa, a violência só poderá ser minimizada quando diminuir a exclusão e a desigualdade na sociedade, mas a estrutura do sistema prisional brasileiro produz cada vez mais morte, indignidade e violência. 


\section{Estéticas da violência e suas reverberações na sociedade cibercultural}

Para Adorno (1992) a acentuada proliferação da violência na sociedade é reflexo de uma modernidade que não se desenvolveu harmonicamente, pois se estruturou com a consolidação do capitalismo. É sob a lei da funcionalidade, pela lógica da multiplicação de mercadorias, que vemos o mundo crescer com o movimento das máquinas e seus solavancos brutos. Desse modo, o autor faz uma analogia à deformação do comportamento humano, cada vez mais privado de liberdade e independência, já que o controle da máquina se estendeu ao controle do homem e do seu pensamento, considerando que o ambiente tecnicista influenciou na perda de consciência e do espírito crítico que são essenciais à liberdade.

A partir desta reflexão fazemos alguns apontamentos e conexões entre a representação da violência no passado e na contemporaneidade. Partimos do exemplo da organização terrorista Estado Islâmico (EI), que tem uma interpretação radical da religião islâmica, e consolidou sua propaganda ideológica por meio de uma linguagem visual extremamente cruel, principalmente ao divulgar vídeos de tortura e execução. Essas ações, cada vez mais elaboradas, reproduzem formatos e estruturas narrativas cinematográficas para divulgar atos de violência.

O pesquisador alemão Bernd Zywietz enfatiza que a comunicação do EI que é distribuída pela internet se baseia em modelos estéticos de filmes hollywoodianos e videogames, principalmente para atrair os jovens. Segundo Zywietz (2016) a estética visual é um apelo marcante para a disseminação da ideologia do grupo que se expressa numa propaganda cara, tecnicamente bem produzida e com simbologias voltadas para apelar às emoções.

Os vídeos são estruturados como filmes de ação, os slogans e a composição gráfica das propagandas trazem referências a elementos da indústria do entretenimento e da cultura pop. Cenas de barbárie como crianças executando prisioneiros, pessoas sendo decapitadas, queimadas, afogadas, jogadas de prédios, fuziladas, são algumas das estratégias do EI para demonstrar seu poder. Além das execuções (verdadeiros shows de horror e tortura) que culminam na morte conjunta de seres humanos, há vídeos em que os líderes do grupo divulgam mensagens, textos, discursos extremistas e diversas outras ações que buscam enfatizar por argumentos religiosos que são vencedores e podem reescrever a história impondo seus valores (ZYWIETZ, 2016). 
Com o avanço da internet, a produção e divulgação de mensagens se torna cada vez mais fluida, o que pode ser eficaz tanto para o desenvolvimento cognitivo e sociocultural quando para a propagação do ódio, conforme Ferrari (2016). Nos campos da Comunicação e da Informação, a autora destaca que os avanços tecnológicos em decorrência da web (com suas múltiplas possibilidades de interação) transformaram o público consumidor em agente, sobretudo, na atuação pelas redes sociais da internet. Conforme a autora, esses novos fluxos provocam incessantemente rupturas nas formas de relações interpessoais e aceleram o crescimento e a multiplicidade de camadas de informação, num movimento em cascata, "como se a todo o instante estivéssemos descascando cebola" (FERRARI, 2016, p 34). Essa angústia por velocidade e informação (principalmente audiovisual já que a internet é a TV da atualidade, pois tem a suplementação da interatividade, mobilidade e ubiquidade) gera desgaste, cansaço, desequilíbrio, mas também potencializa a diversificação de conexões mentais. Ao mesmo tempo em que evidencia posturas cada vez mais reacionárias também pode encontrar espaços para discussões aprofundadas, aponta Ferrari (2016).

$\mathrm{Na}$ sociedade contemporânea, as pessoas se tornaram produtores, criadores, autores de seus próprios conteúdos, o que permite maior troca de mensagem e interação. Ou seja, as transformações que ocorreram superaram ideia de técnica, de política de economia, de tempo e espaço. Isso trouxe mudanças de atitude e comportamento entre os diferentes atores sociais, e ainda novas formas de comunicação e relacionamentos (MONTEIRO, 2017).

Monteiro (2017), resgatando Marshall McLuham, com a ideia dos meios de comunicação como extensões do homem, relaciona o ambiente e os sujeitos com as amplificações sensoriais proporcionadas pelos dispositivos tecnológicos e as mídias digitais, considerando que celulares, notebooks, tablets são extensões do corpo e amplificaram o poder do ser humano de criar conhecimento sobre si e sobre o mundo. Lévy (2014) reconhece as profundas mudanças ocorridas na sociedade nos tempos atuais e chama esse ambiente de ciberespaço, que seria o novo espaço de interações propiciado pela realidade virtual, a partir dos avanços tecnológicos e das dinâmicas de informação e dos meios de comunicação.

O termo 'ciberespaço’ especifica não apenas a infraestrutura material da comunicação digital, mas também o universo oceânico de informação que ela abriga, assim como os seres humanos que navegam e alimentam 
esse universo. Quanto ao neologismo 'cibercultura', especifica aqui o conjunto de técnicas (materiais e intelectuais), de práticas, de atitudes, de modos de pensamento e de valores que se desenvolvem juntamente com o crescimento do ciberespaço (LÉVY, 2014, p. 17).

Ainda não temos distanciamento o suficiente para compreender ou medir os impactos do audiovisual na produção de sentidos da sociedade cibercultural, tamanha velocidade da transformação na relação dos hábitos e comportamentos dos sujeitos com os meios de comunicação e os sistemas econômicos e políticos. Para Ferrari (2016) os grupos criados em redes sociais, como o WhatsApp, exemplificam a inter-relação homem, máquina, tecnologia e os procedimentos sociocomunicacionais. Por meio desse fluxo, a disseminação de vozes e discursos ecoam em diferentes ritmos e intensidades.

Conforme Ferrari (2016, p. 183) o leitor da sociedade contemporânea está nas telas e a visualidade é o mundo que está conectado nas redes sociais, consumindo e gerando conteúdo, pois "o que temos para hoje é o planeta Facebook; gostando ou não da rede social, o mundo conectado está ali, consumindo e gerando conteúdo. A gente virou mais superficial, vão questionar alguns! A gente gosta mais de assistir vídeos do que ler".

Isto nos mostra que a internet possibilitou uma confluência de ideias e descobertas, sobretudo por meio das redes sociais. As pessoas atualmente encontram justificativa em qualquer motivo para expor e socializar suas vidas como uma espécie de publicidade das atividades cotidianas ou de momentos considerados especiais. No caso dos detentos, a expressão da violência talvez revele um desejo de autoafirmação perante a sociedade, de mostrar superioridade em relação aos rivais e de desafiar o Estado. Estas conjecturas podem estar entre as motivações para a divulgação dos vídeos nas redes da internet. Assim, vamos ao encontro ao pensamento de Castells (2009), pois, para o autor a digitalização e a convergência tecnológica podem ser responsáveis por consequências revolucionárias ou transformações sociais imprevisíveis.

Todavia, quando trazemos a questão para o nosso foco de discussão, precisamos ter claro que a estetização da violência não começou com a internet, mas esse multifacetado meio de comunicação midiática pode ter ajudado a pulverizar com mais velocidade e abrangência alguns traços que acompanham a trajetória antropológica da humanidade, tendo em vista que é possível acompanhar as representações da violência desde as pinturas rupestres da pré-história passando por todas as fases sociais e períodos históricos. 
Assim, tomamos a liberdade de ilustrar a discussão com alguns exemplos de domínio público e bastante difundidos pelo senso comum. Uma das histórias mais conhecidas no mundo, a de Jesus Cristo, difundida há mais de dois mil anos é marcada profundamente pela estetização da violência, sobretudo, no processo do martírio, com signos marcantes como a coroa de espinhos, o açoite pelos soldados romanos, o linchamento popular, a brutalidade da crucificação. Na cultura asteca acreditava-se que os sacrifícios humanos eram o que mantinha a existência do sol (seu deus supremo), quando os sacerdotes arrancavam o coração de pessoas vivas. Estes são apenas alguns exemplos que trazem em seu cerne uma série de interesses para a manutenção do poder (seja religioso, político, cultural e econômico). Também nos apontam para uma mise-en-scène construída para sua validação, e que depende e varia conforme uma série de fatores que regem determinada época.

Mello (2011) reforça que fotografias de Lampião (líder do cangaço) e do seu bando mortos (mutilados pela polícia), feitas em 1938, tornaram-se icônicas na representação e estetização da violência. São registros chocantes (e muito parecidos ao que vemos em rebeliões carcerárias atuais), feitos em diferentes ângulos, mas que mostram praticamente o mesmo quadro, com 11 cabeças decapitadas dispostas entre quatro degraus da fachada de uma igreja. Ao lado de cada cabeça uma pequena placa com os nomes dos mortos e ao redor, compondo decorativamente o cenário, os chapéus dos cangaceiros, suas armas, peças de roupas e objetos pessoais. As cabeças, e a montagem desse quadro mórbido, percorreram cidades do sertão nordestino como uma forma de intimidação a quem pretendia se rebelar contra o sistema hegemônico de poder, como reforça Mello (2011).

Nesse sentido, dentro de uma ampla gama de possibilidades que a estética do medo apresenta (na relação com o mórbido e o grotesco), também pode fazer crescer a indiferença pela dimensão que há por traz da representação visual e que varia conforme a época e o contexto sociocultural, como já enfatizamos. No início do século XX, por exemplo, era comum a visita diária de centenas de pessoas ao necrotério de Paris para ver corpos de pessoas mortas, como quem vai a um parque de diversões. Atualmente é possível baixar pela internet um variado repertório audiovisual da banalização da violência, desde games até a ficha de adesão para ingressar no terrorismo internacional. Os aspectos apontados sinalizam que a estética da violência e do medo tem um grande poder de comunicação. 
Na TV, que ainda é um dos principais meios de comunicação, há algumas décadas até mesmo o jornalismo se rendeu às fórmulas de sucesso do apelo ao grotesco, com a veiculação de um turbilhão de imagens de violência física e moral, principalmente em programas policialescos. $\mathrm{O}$ que muitas vezes pode ativar mecanismos psicológicos e influenciar condutas agressivas de comportamento (MATOS, 2005).

Antes da TV, situações violentas também eram exploradas por livros, jornais, revistas e pelo rádio, mas com a televisão houve a suplementação da imagem em movimento, do som e das transmissões ao vivo, trazendo a impressão do telespectador vivenciar os momentos registrados, como aponta Belloni (1998). A autora enfatiza que a banalização da estupidez no cotidiano midiático tem efeito de entretenimento e pode obscurecer a compreensão dos contextos de onde os fatos foram retirados, levando a uma série de interpretações fragmentadas e precipitadas.

A estética da violência pode colaborar para a inversão de valores éticos e para o amálgama entre ficção e realidade, sem estimular a reflexão, conscientização ou ajudar na construção da cidadania, além de perpetuar um imaginário dominado pelo princípio do medo. Essa concepção é traduzida para o audiovisual atendendo às exigências técnicas e mercadológicas das empresas de comunicação, salienta Belloni (1998), ao sugerir que, nesse sentido, reforça-se a construção de uma visão de mundo maniqueísta entre mocinhos e bandidos, cada qual querendo atingir seu momento de glória e autoafirmação. Um processo que vai construindo generalizações e legitimando meios violentos para conquistar sonhos e desejos materiais. Nesse sentido, muitas vezes há uma glamourização ou exacerbação pela aventura da ação criminosa.

Belloni (1998) ao refletir sobre a estética da violência se aproxima da psicanálise e nos situa sobre outros panoramas, reforçando a ideia do pacto edípico, da teoria freudiana, que ocorre quando a criança reprime sua agressividade contra o pai para assegurar sua proteção e afeto. Esse processo, chamado de Lei da Cultura, é uma espécie de acordo psicossocial pelo qual os sujeitos tornam-se membros de uma sociedade e aceitam suas imposições desde que tenham benefícios, como segurança, trabalho e lazer. Porém, quando a sociedade é incapaz de proporcionar tais compromissos ocorre uma ruptura, podendo levar ao desespero e a revolta em vez de cimentar a adesão social.

Esse princípio pode ser associado às práticas criminosas e à violência, que se manifestam desde as camadas mais pobres até as elites, com os cri- 
mes de colarinho branco, provocando uma descrença generalizada na política, na justiça e no Estado. No campo social essa instabilidade gera comportamentos antissociais e de rebeldia, principalmente quando os modelos de representação revelam-se como uma falácia. (BELLONI, 1998).

No mundo inteiro, denúncias e escândalos de corrupção envolvendo governos são divulgados diariamente, assim como as ações das facções criminosas. Entretanto, mesmo pelos trâmites legais, há determinados grupos que são privilegiados em comparação a outros, o que acentua ainda mais os níveis de insatisfação com a deterioração da ideia de direitos igualitários.

Quando observamos essa temática por uma perspectiva ecossistêmica, ou seja, considerando inter-relações e interdependências na articulação entre fatores históricos, socioculturais, ambientais e tecnológicos, percebemos as ambiguidades em seus nós de intersecção. Pois, o Estado já não consegue mais convencer ética e moralmente a população, as elites econômicas sentem suas estruturas abaladas na manutenção do sistema de dominação, atos de barbárie desordenam a lógica de direitos humanos conquistados, intelectuais tecem teorias do topo dos seus castelos de sabedoria, crises sociais e existenciais emergem e difundem-se pelas redes sociais da internet. Assim, na espetacularização da barbárie, "vilões e heróis" se misturam dentro de uma realidade caleidoscópica, onde o simulacro estético amortiza a sensibilidade em relação ao sofrimento, ao trágico, à dor e à miséria, na inversão da civilidade e da justiça cidadã.

Para Baitello Júnior (2005) vivemos sob imposições "iconofágicas" potencializadas pela internet, o que exige a necessidade cada vez maior de produzir e replicar imagens, sem necessariamente refletir sobre seus desdobramentos, gerando um desequilíbrio sensório-cognitivo. Conforme o autor, simultaneamente devoramos e somos devorados pelo turbilhão de imagens a que somos expostos diariamente e essa mudança provocou uma "crise da visibilidade", em função de uma realidade ilustrada por imagens e mediada por aparatos tecnológicos especialmente, pela sua multiplicação exagerada. $\mathrm{O}$ mesmo mecanismo cultural que pode promover a diversidade também é perverso, quando tende a transformar o complexo e profundo em superficial, transladando as vivências das experiências humanas e das relações de afetividade para representações construídas por imagens. 


\section{A rebelião do Compaj na Rede}

Antes da rebelião do Compaj ser controlada começaram a circular imagens feitas de dentro do presídio por celulares de internos e postadas nas redes sociais da internet. Tais postagens se disseminaram rapidamente, por meio de compartilhamentos entre a população, mostrando a gravidade do conflito, a barbaridade das circunstâncias e as inúmeras falhas de segurança na unidade prisional. A reportagem da BBC Brasil foi a primeira equipe de jornalismo a entrar no interior do Compaj, uma semana após a rebelião. Acompanhando uma comitiva formada por políticos e representantes de ONGs, a reportagem conseguiu passar pela segurança, com um celular, sem ser revistada, e dentro das alas do presídio constatou que o sinal e a velocidade da conexão à internet "estavam ótimos", como enfatiza a publicação (BBC BRASIL, 2017).

Em reportagem publicada no dia 05 de janeiro de 2017 (O GLOBO, 2017), enfatiza-se que as câmeras internas do Compaj registraram toda a ação do massacre, e que os presos que comandaram a rebelião, praticaram as torturas e os assassinatos não se preocuparam em esconder o rosto. Na reportagem menciona-se ainda que os investigadores do caso acreditam que, pelo fato dos equipamentos de monitoramento não terem sido destruídos na revolta, a intenção dos detentos era que a matança fosse assistida pelas autoridades e pela sociedade.

Além das cenas que as câmeras do circuito interno de monitoramento captaram, também chamam a atenção as imagens produzidas e divulgadas pelos presos em redes sociais da internet. Uma das primeiras imagens a circular pelo WhatsApp, com compartilhamentos diversos entre a população local e também divulgada pela mídia (O GLOBO, 2017), é um vídeo que mostra a comemoração dos líderes da rebelião empunhando facões, escopetas e uma pistola.

Em um vídeo do YouTube 5 , intitulado "Imagens Fortes! Rebelião na penitenciaria COMPAJ BR174 Manaus" um presidiário circula por um dos pavilhões do Compaj mostrando o resultado da rebelião. É praticamente um web-documentário mórbido que revela o cenário de destruição com corpos mutilados em corredores banhados de sangue. $\mathrm{O}$ interno rebelado passeia por entre cabeças decepadas, pernas e braços amontoados pelos cantos. Numa outra postagem disponibilizada pelo

\footnotetext{
${ }^{5}$ Advertimos que os links a seguir remetem a conteúdos com cenas extremamente chocantes.

${ }^{6}$ Disponível em: <https://www.youtube.com/watch?v=p6fonnFZKOg> Acesso em 19 jan. 2017.
} 
YouTube, "Rebelião em Manaus pat 1 - FDN exibem cabeças dos PCC's - Manaus AM"7 um dos integrantes da FDN apresenta, como troféus, as cabeças dos principais integrantes do PCC que estavam no Compaj, falando o nome de cada um deles com o entusiasmo pelo feito e a indiferença pela morte. Lembra muito o caso relatado anteriormente sobre as cabeças expostas do bando de Lampião, porém, nesta situação por uma lógica inversa.

O site da Revista Veja, em 02 de janeiro de 2017, publicou a manchete "No Amazonas, criminoso em fuga posta foto em rede social" (VEJA, 2017). A notícia é sobre um dos detentos que conseguiram fugir durante a rebelião e fez postagem no Facebook. Na imagem que ilustra a reportagem, o fugitivo aparece em uma selfie ao lado de um companheiro, no meio da mata, fazendo pose. Destaca-se o gesto com o punho fechado e o polegar estendido para cima, sinalizando positivo ou o popular "curtir" da linguagem da internet. Na legenda, o texto escrito pelo presidiário, diz: "Na fulga (sic) da cadeia". A reportagem apurou que o presidiário mantinha seu perfil com postagens constantes e na semana anterior à rebelião já havia manifestado que a FDN planejava alguma ação para ser executada em breve. Também chegou a postar a seguinte frase: "Se toda a alegria é passageira, nenhum massacre será eterno. Liberdade".

Outros vídeos e fotos, tão chocantes quanto os vídeos supracitados, postados durante o massacre do Compaj, viralizaram entre as redes sociais e também ilustraram as pautas de jornais, revistas, sites, e programas de televisão. Ressaltamos que este não é um caso isolado, pois, além da rebelião de Manais, em outros motins a estratégia de detentos usarem as redes sociais para transmitir massacres ao vivo tornou-se corriqueira, numa espécie de espetacularização do cotidiano e da violência.

A partir das discussões nos itens anteriores, ao interpretarmos a produção e a divulgação destas imagens pelos internos, numa perspectiva ecossistêmica, podemos sugerir que os autores pretendiam passar a ideia de tomada do poder, numa autoafirmação dos códigos de ética estabelecidos pela facção FDN, sobrepondo-se aos códigos do PCC. Assim, quando resgatamos a discussão em torno de psicanálise, da estética, da espetacularização midiática e dos processos sociais, percebemos que desta maneira, ao tentarem legitimar sua causa por meio da violência, os presidiários quebram valores institucionais da sociedade civil organizada e do seu Governo, que não lhes deram afeto e segurança.

\footnotetext{
${ }^{7}$ Disponível em: <https://www.youtube.com/watch?v=KPntTcHcLx0> Acesso em 19 jan. 2017.
} 
Nesse sentido, a estética da selvageria se expressa em comportamentos antissociais e de rebeldia, estimulados pela descrença numa Justiça, que no discurso e na promulgação das leis prevê direitos iguais para todos, mas na ótica de quem se sente desfavorecido, beneficia as elites econômicas e o poder institucionalizado. Assim, canibalizam (sugerindo um termo iconofágico) os modelos de representação midiáticos que são alicerçados no maniqueísmo (heróis $\mathrm{x}$ vilões) e transgridem imposições sociais (de vilões passam a ser heróis dentro de suas perspectivas), em busca de concretizar o sonho da liberdade, como um deles chega a expressar textualmente em uma postagem já mencionada. A espetacularização da crueldade se aproxima da estética da ficção pela banalização da estupidez no cotidiano midiático. Torna-se quase uma forma de entretenimento que pode prejudicar a compreensão da complexidade dos seus contextos e inverter valores éticos.

Portanto, mostram à sociedade, por meio das imagens, que venceram os rivais criminosos e o próprio Estado. Reforçam a força da "comunidade" (facção criminosa) e do "novo governo" (do cárcere). Exibem com orgulho o armamento que circula na unidade prisional, fazendo questão de enfatizar que não estão apartados das possibilidades de comunicação, afinal, nas conexões em rede podem articular estratégias criminosas, praticá-las e divulgá-las. O que desmoraliza toda a estrutura e a eficiência dos órgãos de Segurança Pública. Representa a vitória do crime perante a decadência do encarceramento social, evidenciando que seus tentáculos muito poderosos e encontram nas fragilidades do sistema diversas maneiras de se fortalecer e continuar suas ações.

É importante reforçar que a disseminação de imagens feitas por presidiários não se restringe apenas às rebeliões citadas e nem somente a ações criminosas. Também podem funcionar como uma possibilidade de denúncia. Na internet, por meio de buscas dirigidas, é possível localizar centenas de vídeos que mostram o interior das unidades prisionais e situações do cotidiano nesses locais, pela ótica dos presidiários. Assim, chega ao alcance da sociedade uma pequena mostra das condições insalubres em que se encontra a população carcerária. Relatos que vão desde a exposição de violência e discursos de ódio até pedidos de socorro, reivindicações por melhorias no atendimento à saúde, alimentação e condições de higiene e limpeza. Independente de circunstâncias morais ou jurídicas, o que se percebe claramente nessa(s) estética(s) da violência, é que as unidades prisionais brasileiras potencializam a opressão, as 
revoltas e a falta de civilidade. Esse é um sinal muito forte para pensarmos não só na crise do sistema penitenciário brasileiro, mas na crise da sociedade contemporânea global e na produção de sentidos pela comunicação audiovisual em rede.

\section{Considerações finais}

Neste artigo procuramos apresentar uma possibilidade de leitura ecossistêmica comunicacional, sobre a estetização da violência na sociedade cibercultural, a partir de apontamentos sobre uma série de rebeliões prisionais ocorridas no Brasil no início de 2017, com enfoque no caso do Compaj, em Manaus. Além de contextualizarmos a temática, com base em sua cobertura jornalística e sobre diversos aspectos socioculturais, reforçamos a questão das representações na linguagem audiovisual (da estetização de assassinatos), por meio da produção de imagens por internos do Compaj, divulgadas nas redes sociais da internet e muitas vezes replicadas por veículos de comunicação tradicionais.

Seguindo o viés dos Ecossistemas Comunicacionais, nosso intuito foi mais de provocar reflexões do que buscar respostas objetivas. Aliás, a compreensão sobre Ecossistemas Comunicacionais implica ter flexibilidade de entendimento e percepção e, por isso, quem se propõe a pesquisar por esse viés não deve pensar, necessariamente, em uma aplicação prática, mas exercitar a busca de multiplicidades, permitindo que a criatividade e os afetos ganhem espaço na produção do conhecimento científico, que é uma construção do pondo de vista epistemológico.

Assim, a partir de uma discussão dialógica entrelaçada por conceitos teóricos, pela observação da produção e divulgação de imagens por internos de unidades prisionais durante rebeliões e por reportagens da mídia noticiando esses fatos, construímos um mosaico interpretativo. Reforçamos que a nossa leitura para este mosaico também é uma construção e está transformação constante. Afinal, temos consciência de que no momento em que descrevemos estas impressões, o panorama outrora observado já estará modificado e sujeito a outras variáveis.

Mas, por meio da nossa leitura transitória (que poderá ser desdobrada e aprofundada em estudos posteriores), percebemos que na contemporaneidade a imagem, o som, as emoções, as sensações, o pensamento e as ações estão "corporificados" no espaço hipermidiático, transitando num emaranhado de circuitos relacionais e interdependentes. Nesse 
sentido, as manifestações midiáticas que configuram uma "estética da violência" expressadas em diferentes situações (mas com grande tendência à supremacia audiovisual devido à internet), paradoxalmente, ganham uma dimensão cada vez mais complexa no contra fluxo de sua efemeridade, sobretudo, pelo poder da imagem na produção de sentidos e na desconstrução dos mesmos.

Assim, não só os conteúdos que produzimos ou divulgamos, mas nossas relações interpessoais tendem a se aproximar cada vez mais de narrativas espetaculosas, fragmentadas e sensacionalistas, que apelam às emoções para reforçar laços afetivos ou acentuar as dicotomias sociais. Portanto, nosso intuito foi sinalizar algumas inter-relações entre fatos ocorridos no cotidiano e suas interdependências culturais, evidenciando a complexidade da comunicação midiática de uma sociedade entrelaçada pela violência. Não importando se estamos dentro ou fora das grades, no mundo real ou no mundo virtual, já que pelas redes online (quase) não há obstáculos nem fronteiras.

\section{REFERÊNCIAS}

ADORNO, Theodor. Minima Moralia - Reflexões a partir da vida danificada. São Paulo: Editora Ática, 1992.

AMARAL, Adriana; NATAL, Geórgia; VIANA, Lucina. Netnografia como aporte metodológico da pesquisa em comunicação digital. In: Revista Sessões do Imaginário, PUC-RS, Porto Alegre, v. 2, n. 20, p.34-40, dez. 2008.

AMORIM, Carlos. CV-PCC: a irmandade do crime. Editora Record, 2003.

BAITELLO JUNIOR, Norval. A Era da Iconofagia: Ensaios de Comunicação e Cultura. São Paulo: Hacker Editores, 2005.

BBC BRASIL. Palco de chacinas, presídios têm internos bebendo água de privada e sinal de celular. Disponível em: <https://noticias.uol.com.br/ultimas-noticias/ bbc/2017/01/11/mais-de-uma-semana-apos-chacinas-presidios-tem-marca-de-tiroe-internos-bebendo-agua-de-privada.htm> Acesso em 19 jan. 2017.

BELLONI, Maria Luiza. Estética da Violência. In: Comunicação \& Educação - Revista do Departamento de Comunicação e Artes da ECA/USP, São Paulo, n. 12, 1998. Disponível em: <http://www.revistas.usp.br/comueduc/article/ view/36357/39077> Acesso em 18 jan. 2017.

CARTA CAPITAL. Carnificina em presídios deixou mais de $\mathbf{1 3 0}$ mortos neste 
ano. São Paulo: Confiança, 2017. Disponível em: <http://www.cartacapital.com.br/ sociedade/carnificina-em-presidios-deixou-mais-de-130-mortos-neste-ano > Acesso em 15 jan. 2017.

CASTELLS, Manuel. A galáxia da internet: reflexões sobre a internet, negócios e a sociedade. Rio de Janeiro: Jorge Zahar, 2009.

\section{COLFERAI, Sandro Adalberto. A Amazônia como metáfora do ecossistema} comunicacional: uma leitura do conceito a partir da região. Tese (Doutorado em Sociedade e Cultura na Amazônia). Universidade Federal do Amazonas, Programa de Pós-Graduação em Sociedade e Cultura na Amazônia. Manaus: UFAM, 2014.

ÉPOCA. O crime está em guerra: as maiores facções brasileiras romperam - As rebeliões em presídios são um aviso. A selvageria está à solta. G1: Organizações Globo, 2017. Disponível em: <http://epoca.globo.com/tempo/noticia/2016/10/ocrime-esta-em-guerra-maiores-faccoes-brasileiras-romperam.html> Acesso em 17 jan. 2017.

FERRARI, Pollyana. Comunicação digital na era da participação. Porto Alegre: Editora Fi, 2016.

FOLHA DE S.PAULO. Temer fala em crise nacional e anuncia Forças Armadas dentro de presídios. São Paulo: Grupo Folha, 2017. Disponível em: <http://www1. folha.uol.com.br/cotidiano/2017/01/1850566-temer-fala-em-crise-nacional-eanuncia-forcas-armadas-dentro-de-presidios.shtml> Acesso em 17 jan. 2017.

JORNAL NACIONAL. Crise nas cadeias leva secretários de Segurança a se reunirem em Brasília. G1: Organizações Globo, 2017. Disponível em: <http:// g1.globo.com/jornal-nacional/noticia/2017/01/crise-nas-cadeias-leva-secretarios-deseguranca-se-reunirem-em-brasilia.html> Acesso em 17 jan. 2017.

LÉVY, Pierre. Cibercultura. São Paulo: Ed. 34, 2014.

MATOS, Armanda. Televisão e violência: (para) novas formas de olhar. In: Comunicar- Revista científica ibero-americana de comunicação e educação, Espanha, v.2 n. 25, 2005.

MELLO, Frederico. Guerreiros de Sol - Violência e Banditismo no Nordeste do Brasil. São Paulo: Girafa, 2011.

MÍDIA NINJA. Cadê os direitos humanos? Rede de narrativas independentes, jornalismo e ação: Oximity, 2017. Disponível em: <https://ninja.oximity.com/article/ Cad\%C3\%AA-os-direitos-humanos-Entrevi-1> Acesso em 16 jan. 2017.

MONTEIRO, Gilson; ABBUD, Maria Emília; PEREIRA, Mirna (orgs.). Estudos e perspectivas dos ecossistemas na comunicação. Manaus: Edua/UFAM, 2012. 
MONTEIRO, Gilson. Mídias digitais e as tecnologias da sobrevivência. In: Paulus Revista de Comunicação da FAPCOM, São Paulo, v.1, n. 1, p. 109-121, 2017.

O GLOBO. Câmeras da prisão registraram chacina em Manaus. Disponível em: <http://oglobo.globo.com/brasil/cameras-da-prisao-registraram-chacina-emmanaus-20730366> Acesso em 19 jan. 2017.

PASTORAL CARCERÁRIA. Massacres: Não é crise, é projeto. Conferência Nacional dos Bispos do Brasil (CNBB), 2017. Disponível em: <http://carceraria.org.br/wpcontent/uploads/2017/01/Nota_Massacres-.pdf > Acesso em 19 jan. 2017.

PIETÁ, Elói; PEREIRA, Justino. Pavilhão 9: o massacre do Carandiru. Scritta Editorial, 1993.

UOL. Rebelião em presídio termina com ao menos 56 mortos em Manaus, diz governo. Universo Online, 2017. Disponível em: <https://noticias.uol.com.br/ cotidiano/ultimas-noticias/2017/01/02/rebeliao-no-amazonas-termina-com-aomenos-50-mortos-diz-governo.htm> Acesso em 15 jan. 2017.

VEJA. No Amazonas, criminoso em fuga posta foto em rede social. Disponível em: $<$ http://veja.abril.com.br/brasil/no-amazonas-criminoso-em-fuga-posta-foto-emrede-social/> Acesso em 19 jan. 2017.

ZYWIETZ, Bernd. Terrorismo, propaganda \& mídia. Universidade de Mainz, 2016. Disponível em: <http://www.bzyw.de/?page_id=59> Acesso em 18 jan. 2017. 